\title{
Forthcoming meetings convened by the Conference of the European Statisticians
}

Work session on marine water quality statistics (Geneva, February 1992)

The work session will discuss the development of a draft ECE Standard Statistical Classification of marine water quality, Issues to be dealt with include selection and structuring of variables and determination of class ranges for units for the variables.

Meeting on waste statistics (Geneva, March 1992)

The meeting will deal with the results of the test of the draft ECE Standard Statistical Classification of Wastes and the revision of the classification.

Working session on housing statistics (Geneva, March 1992)

This work session has been convened jointly by the Conference of European Statisticians and the Committee on Human Settlements. The participants will discuss (i) statistics relating to distribution and quality aspects of housing; (ii) progress in the development of statistics on housing improvements, repairs, and maintenance; and (iii) topics in the field of housing statistics of priority interest to transition countries.

Work session on statistical data editing (Washington, D.C., United States, March 1992)

The work session will continue to elaborate methodological materials on the following topics: (i) data editing methods, techniques, and software; (ii) data editing system guidelines for concepts and specification; (iii) impact of data editing on quality of data; (iv) new technologies in data editing; (v) collection and editing of data from administrative soures; (vi) and automated coding. 